(D) Lerzan Doğan,
(D) Canan Akıncı,

(D) Zeynep Tuğçe Sarıkaya,

(D) Hande Simten Demirel Kaya,

(D) Rehile Zengin,

(D) Orkhan Mammadov,

(D) Aylin İlksoz,

(D) İlkay Kısa Özdemir,

(D) Meltem Yonca Eren,

(D) Nazire Afsar,

(D) Sesin Kocagöz,

(D) İbrahim Özkan Akıncı

Received/Geliş Tarihi : 13.11.2020

Accepted/Kabul Tarihi : 07.12.2020

${ }^{(C)}$ Copyright 2021 by Turkish Society of Intensive Care Turkish Journal of Intensive Care published by Galenos Publishing House.

Lerzan Doğan, Zeynep Tuğçe Sarıkaya, Hande Simten Demirel Kaya, Orkhan Mammadov, Aylin Ilksoz, Ilkay Kısa Özdemir, Ibrahim Özkan Akıncı

Acıbadem Altunizade Hospital, Clinic of Intensive

Care, Istanbul, Turkey

Canan Akıncı, Meltem Yonca Eren

Acıbadem Fulya Hospital, Clinic of Intensive Care,

Istanbul, Turkey

Rehile Zengin

Acıbadem Altunizade Hospital, Clinic of Infectious

Diseases and Clinical Microbiology, Istanbul, Turkey

Nazire Afsar

Acıbadem Mehmet Ali Aydınlar University; Acıbadem Altunizade Hospital, Clinic of Neurology, Istanbul,

Turkey

Sesin Kocagöz

Acıbadem Mehmet Ali Aydınlar University; Acıbadem Altunizade Hospital, Clinic of Infectious Diseases and Clinical Microbiology, Istanbul, Turkey

Lerzan Doğan MD, (函)

Acıbadem Altunizade Hospital, Clinic of General

Intensive Care Unit, Istanbul, Turkey

E-mail : : Iredzheb@gmail.com

Phone : +90 5071993754

ORCID ID : orcid.org/0000-0002-1456-4072

\section{Human Metapneumovirus Infection in Adults as the Differential Diagnosis of COVID-19}

\author{
COVID-19 Ayırıcı Tanısı Olarak Yetişkinlerde Insan \\ Metapnömovirüs Enfeksiyonu
}

ABSTRACT Human metapneumovirus (HMPV) is a respiratory tract virus identified 18 years prior to severe acute respiratory syndrome coronavirus-2. Both viruses cause acute respiratory failure characterised by a rapid onset of widespread inflammation in the lungs with clinical symptoms similar to those reported for other viral respiratory lung infections. HMPV, more generally known as childhood viral infection, causes mild and self-limiting infections in the majority of adults, but clinical courses can be complicated in risky groups and associated morbidity and mortality are considerable. Moreover, adults are not regularly screened for HMPV and the prevalence of adult HMPV infections in Turkey is unknown, with previous reports in the paediatric population. This should always be kept in mind during the coronavirus disease-2019 pandemic, particularly when neurological complications are added to respiratory findings. In our study, two adult cases of HMPV pneumonia and encephalitis have been recorded.

Keywords: Metapneumovirus infection, acute respiratory infections, neurological involvement, wide respiratory screening

ÖZ Insan metapnömovirus (HMPV), şiddetli akut solunum sendromu koronavirüs-2'den 18 yıl önce tanımlanan yeni solunum yolu virüsüdür. Bilinen diğer viral solunum yolu enfeksiyonlarına benzer klinik semptomlarla sahip olup, her iki virüs de akut solunum yetersizliğine neden olabilir. HMPV çocukluk çağı solunum yolu enfeksiyonu olarak bilinse de, yetişkinlerin çoğunda hafif ve kendini sınırlayan enfeksiyonlara neden olur, hatta riskli hastalarda klinik seyir komplike olup ciddi morbidite ve mortaliteye neden olabilir. Yetişkinler viral enfeksiyon durumunda rutin olarak HMPV için taranmadığından Türkiye'de HMPV enfeksiyonlarının prevalansı bilinmemektedir ve önceki rapor edilen olgular pediatrik popülasyonda yer almaktadır. Koronavirüs hastalığı-2019 pandemisi sırasında özellikle solunum bulgularına nörolojik komplikasyonlar eklendiğinde akılda tutulmalıdır. Bu raporda HMPV pnömonisi ve ensefaliti olan iki yetişkin olguyu sunmaktayız.

Anahtar Kelimeler: Metapnömovirüs enfeksiyonu, akut solunum yolu enfeksiyonları, nörolojik tutulum, geniş respiratuvar tarama 


\section{Introduction}

Human metapneumovirus (HMPV) is a respiratory tract virus identified 18 years before severe acute respiratory syndrome coronavirus-2 (SARS-CoV-2). Both viruses cause acute respiratory failure characterized by rapid onset of widespread inflammation in the lungs with clinical symptoms similar to those reported for other viral respiratory lung infections (1). HMPV is known as childhood infection, but can cause life-threatening infections especially in the frail elderly and the immunocompromised patients $(2,3)$. Adults are not routinely screened for HMPV and prevalence of adult HMPV infections in Turkey is unknown, previous reports were in the pediatric population. However, it should always be kept in mind during coronavirus disease-2019 (COVID19) pandemic especially when neurological complications are added to respiratory findings. We report two adult cases with HMPV pneumonia and encephalitis.

\section{Case Reports}

A first case was a 69-year-old woman with hypertension and Addison's disease. She was admitted to a hospital with fever and dyspnea during SARS-CoV-2 pandemic. At hospital admission, her level of consciousness and the neurological examination was normal. She was transferred directly to our intensive care unit (ICU) due to respiratory failure and non-invasive mechanical ventilation (NIMV) support with a helmet mask was started. Reverse real-time transcriptase polymerase chain reaction (PCR) for COVID-19 was negative and chest computed tomography (CT) was compatible with viral pneumonia. During COVID-19 outbreak because of the situations where the first PCR for COVID-19 can be negative, we initially started treatment against SARS-CoV-2. However, as the respiratory failure progressed she was intubated on the $3^{\text {th }}$ ICU day. Antibiotherapy was changed to piperacillin/ tazobactam + vancomycin. Mechanical ventilation was started with pressure-controlled ventilation mode, pressure controlled level (PC): $16 \mathrm{cmH}_{2} \mathrm{O}$, positive end-expiratory pressure (PEEP): $10 \mathrm{cmH}_{2} \mathrm{O}, \mathrm{FiO}_{2}: 70 \%$, but respiratory acidosis and hypoxia persisted and prone ventilation has been used. She was prescribed $5 \mathrm{mg}$ prednisolone due to Addison's disease, steroid treatment of stress dose was arranged by consulting endocrinology. Laboratory tests showed lymphopenia and elevated inflammatory markers. A nasopharyngeal swab specimen was identified as positive for HMPV using duplex reverse transcription PCR. On the $11^{\text {th }}$ day the inflammatory markers were almost normalized and chest X-ray was better, so sedoanalgesia was gradually reduced. However, $48 \mathrm{~h}$ following cessation of all sedation the patient did not regain consciousness and neurology consultation was performed. Cranial magnetic resonance imaging (MRI), including diffusion-weighted and contrastenhanced series showed bilateral frontal signal changes compatible with meningoencephalitis. MRI findings were suggestive of acute encephalitis with a concomitant acute demyelinating process. Lumbar puncture revealed normal glucose and high protein levels, cell count, IgG index and albumin were within normal limits and no viruses could be isolated in the cerebrospinal fluid (CSF). Oligoclonal bands were negative. Intravenous corticosteroid treatment (1 mg/ $\mathrm{kg} / 24 \mathrm{~h})$ followed by plasmapheresis with albumin was initiated and performed on alternate days for five cycles. The patient developed generalized tonic-clonic seizure, so sedation was deepened with thiopental, midazolam and fentanyl. General condition of the patient worsened, lymphopenia and inflammatory marker elevation persisted with refractory fever around $40{ }^{\circ} \mathrm{C}$. All potential infectious sources were ruled out, antibiotherapy was escalated and inotropic support has been increased significantly. However, cardiac arrest developed on the $16^{\text {th }} \mathrm{ICU}$ day, and cardiopulmonary resuscitation was unsuccessful.

The second case was an 82-year-old woman with atrial fibrillation and hypertension. She presented fever and worsening dyspnea, a diagnosis of viral pneumonia was confirmed by chest CT. Reverse real-time transcriptase PCR for SARS-CoV-2 was negative. She was hospitalized directly in the ICU and started NIMV support with a helmet mask. During coronavirus pandemic we started treatment accepting patients as PCR positive for COVID-19 without waiting for the result. Laboratory tests showed lymphopenia and elevated inflammatory markers. On the third day of admission, her respiratory failure required endotracheal intubation and mechanical ventilation (PC mode, PC: $20 \mathrm{cmH}_{2} \mathrm{O}$, PEEP: 14 $\mathrm{CmH}_{2} \mathrm{O}, \mathrm{FiO}_{2} 50 \%$ ). A nasopharyngeal swab specimen was identified as negative for COVID-19 and positive for HMPV. On the $12^{\text {th }}$ of ICU day with the normalization of infectious markers and improvement of chest X-ray, sedation was gradually reduced and stopped. She was awake with delirium which couldn't be explained by any metabolic occurrence, and was extubated under maximum doses of haloperidol and dexmedetomidine. Neurology consultation was performed, but MRI or lumbar puncture (LP) wasn't performed due to 
the lessening of symptoms. The patient was discharged to a ward on the $14^{\text {th }}$ day of ICU treatment. Agitation decreased but persisted despite treatment even after discharged to a ward. The patients remained physically and cognitively impaired despite rehabilitation. The neuropsychological assessment showed mild difficulties on social abilities.

\section{Discussion}

To the best of our knowledge, this is the first case report of HMPV infection in adults from Turkey. Our first case support consideration of HMPV as a causative agent of acute central nervous system (CNS) involvement after respiratory tract infection in adults. The clinical presentation, laboratory and CSF results, and radiologic findings supported the diagnosis of encephalitis. CSF examinations showed elevated protein with no marked pleocytosis typically seen in viral encephalitis and similar to cases of COVID-19-related CNS involvement (4). The presence of severe agitation in the second case suggests CNS involvement, but we do not have MR and LP evidence to support this hypothesis.

HMPV infection can not be distinguished from other respiratory viruses on clinical and laboratory findings only (5). Compared to other respiratory viruses it has similar rates of ICU admission, mechanical ventilation, and length of stay for hospitalization (6). Neurotropic potential of HMPV seems to be one of the main pathologic mechanisms of these infections. CNS involvement is documented in both children and adults (7-9). Moreover, in many cases of encephalitis of unknown etiology, HMPV has been simultaneously detected in the respiratory tract. The mechanism by which the CNS is affected by the virus is unclear, and treatment approaches are not well defined (10). The fact that we could not demonstrate the virus from CSF may point toward the role of autoimmune inflammatory response as the pathogenic factor in CNS involvement or the timing of viral isolation from CSF had passed.

HMPV at present is still without specific antiviral therapy and managing HMPV-encephalitis is a challenge for intensivists (11). Current clinical management as with COVID-19 includes infection prevention and control measures and supportive care, including supplemental oxygen or mechanical ventilatory support, and advanced supportive therapy like plasmapheresis and steroid therapy when indicated.

The presented cases emphasize the importance of a wider respiratory screening in viral pneumonias. HMPV should be kept in mind when no other etiological agent can be found in the presence of viral pneumonia and CNS involvement findings. Determination of the etiological agent may prevent the use of unnecessary antibiotics. Further studies and treatment strategies are necessary to augment the therapeutic approach in these patients.

\section{Ethics}

Informed Consent: Due to pandemic conditions consent was taken by phone from patient relatives.

Peer-review: Internally peer-reviewed.

\section{Authorship Contributions}

Surgical and Medical Practices: L.D., C.A., Z.T.S., H.S.D.K., O.M., A.I., I.K.Ö., M.Y.E., N.A., S.K., I.Ö.A., Concept: L.D., Z.T.S., R.Z., O.M., A.I., S.K., I.Ö.A., Design: L.D., Z.T.S., O.M., S.K., I.Ö.A., Data Collection or Processing: L.D., C.A., Z.T.S., H.S.D.K., O.M., A.I., I.K.Ö., M.Y.E., I.Ö.A., Analysis or Interpretation: L.D., C.A., Z.T.S., H.S.D.K., R.Z., S.K., I.Ö.A., Literature Search: L.D., Z.T.S., H.S.D.K., R.Z., O.M., S.K., I.Ö.A., Writing: L.D., I.Ö.A.

Conflict of Interest: No conflict of interest was declared by the authors.

Financial Disclosure: The authors declared that this study received no financial support. 


\section{References}

1. Li YC, Bai WZ, Hashikawa T. The neuroinvasive potential of SARS-CoV2 may play a role in the respiratory failure of COVID-19 patients. J Med Virol 2020;92:552-5.

2. van den Hoogen BG, de Jong JC, Groen J, Kuiken T, de Groot R, Fouchier $R A$, et al. A newly discovered human pneumovirus isolated from young children with respiratory tract disease. Nat Med 2001;7:719-24.

3. Haas LE, Thijsen SF, van Elden $L$, Heemstra KA. Human metapneumovirus in adults. Viruses 2013;5:87-110.

4. Dogan L, Kaya D, Sarikaya T, Zengin R, Dincer A, Akinci IO, et al. Plasmapheresis treatment in COVID-19-related autoimmune meningoencephalitis: Case series. Brain Behav Immun 2020;87:1558.
5. Stockton J, Stephenson I, Fleming D, Zambon M. Human metapneumovirus as a cause of community-acquired respiratory illness. Emerg Infect Dis 2002;8:897-901.

6. Widmer K, Zhu Y, Williams JV, Griffin MR, Edwards KM, Talbot HK. Rates of hospitalizations for respiratory syncytial virus, human metapneumovirus, and influenza virus in older adults. J Infect Dis 2012;206:56-62.

7. Sánchez Fernández I, Rebollo Polo M, Muñoz-Almagro C, Monfort Carretero L, Fernández Ureña S, Rueda Muñoz $A$, et al. Human Metapneumovirus in the Cerebrospinal Fluid of a Patient With Acute Encephalitis. Arch Neurol 2012;69:649-52.

8. Vehapoglu A, Turel O, Uygur Sahin T, Kutlu NO, Iscan A. Clinical Significance of Human Metapneumovirus in Refractory Status Epilepticus and Encephalitis: Case
Report and Review of the Literature. Case Rep Neurol Med 2015;2015:131780.

9. Fok A, Mateevici C, Lin B, Chandra RV, Chong VH. Encephalitis-Associated Human Metapneumovirus Pneumonia in Adult, Australia. Emerg Infect Dis 2015;21:2074-6.

10. Arnold JC, Singh KK, Milder E, Spector SA, Sawyer MH, Gavali S, et al. Human metapneumovirus associated with central nervous system infection in children. Pediatr Infect Dis J 2009;28:1057-60.

11. Schildgen $V$, van den Hoogen $B$, Fouchier R, Tripp RA, Alvarez R, Manoha C, et al. Human Metapneumovirus: lessons learned over the first decade. Clin Microbiol Rev 2011;24:734-54. 